\title{
The Effect of the Application of Discovery Learning and Problem Based Learning Model on Metacognitive Ability and Students' Mathematical Connections
}

\author{
Rini Triana ${ }^{1+} \quad{ }^{\prime}$ Master Program of Mathematics Education,Universitas Muhammadiyah of Sumatera Utara \\ Zainal Azis ${ }^{2} \quad{ }^{2, s}$ Universitas Muhammadiyah of Sumatera Utara \\ Irvan $^{3}$
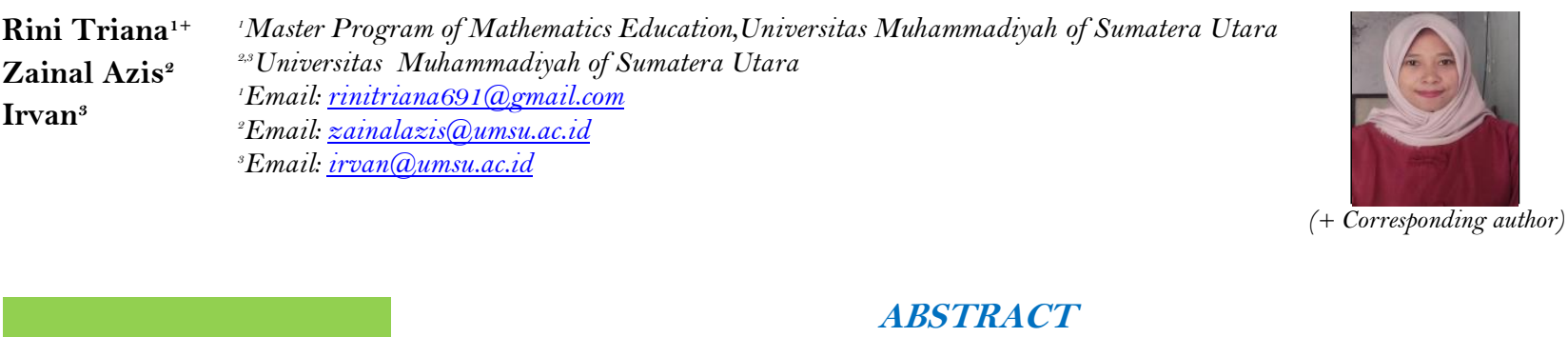

ABSTRACT

Article History

Received: 4

Revised:

Accepted:

Published:

Keywords

Discovery Learning, Problem

Based Learning, Metacognitive Ability, Students' Mathematical Connections
This study aims to determine: (1) the significant influence between learning models on metacognitive abilities, (2) significant effects between learning models on mathematical connections, (3) the interaction between discovery learning and problem based learning on metacognitive abilities, (4) the interaction between discovery learning and problem based learning models on students' mathematical connections. This research is a quasi experimental research. The instruments used were: (1) tests of students 'initial mathematical abilities (2) tests of metacognitive abilities, (3) tests of students' mathematical connections with the subject of Lines and Angles. Inferential data were performed using covariance analysis (MANOVA). The result of hypothesis testing shows that the average metacognitive ability in learning using discovery learning learning models is $77.20>75$ with a standard deviation of 2.161 and students' mathematical connections obtained are $83.63>45$ with a standard deviation of 3.480. By using the problem base learning model is $76.76>75$ with a standard deviation of 2.216 and for the average mathematical connection of the students obtained 81.84 > 45 with a standard deviation of 2.096. The data show that the metacognitive abilities and mathematical connections of students who are taught using discovery learning models are better than those who are taught using problem-based learning models

\section{INTRODUCTION}

Learning is the interaction between students and teachers, there will be intense and directed communication in order to achieve the goals to be achieved. A good learning process requires a process of interaction by all components involved in learning both between students and teachers and students and students. Several aspects in the process of good interaction in learning are giving perception and conveying learning objectives. The success of a lesson can be seen from the results of the teaching and learning process. However, in reality the learning outcomes obtained by students are not in accordance with what the teacher wants.

In fact, the facts in the field have not shown satisfactory mathematics learning outcomes. From the results of observations of the value and activities of Class VII students of the UPT Formal Education Unit at SMP N 1 Percut Sei Tuan, in learning mathematics the researchers can conclude that students still experience difficulties in learning mathematics so that the pattern of answers when solving problems does not vary, the mathematics learning outcomes obtained still not satisfying.

Based on an interview at the UPT Formal Education Unit at SMP Negeri 1 Percut Sei Tuan with Mrs. Rahawarni, who is a teacher in the field of mathematics, said that the data for September 2018 from the results of daily tests of students in grades VII-1 and VII-2 were still low or had not yet met the criteria. minimum completeness $(\mathrm{KKM})$. Because from the results of these tests, the students of class VII-1, totaling 32 students, were still 15 people who had completed or had reached the minimum completeness criteria (KKM). Meanwhile, in class VII-2, which also numbered 32 students, it turned out that there were still 10 students who had completed or had reached the minimum completeness criteria (KKM).

Based on the answers the students' lack of thoroughness occurs for several reasons, as follows. 1). Lack of students' ability to observe and recognize mathematics problems 2). The low ability of students when communicating mathematics using symbols, diagrams, tables, and other media. From the researcher's observations that there are still students who tend to be less active. Things that happen in the field are due to a lack of self-confidence from students when students want to express their opinions in front of the teacher and their friends. This can be one of the triggers for low metacognitive abilities. From the existing conditions in the field, a learning model is needed that can develop metacognitive abilities and students' self-confidence in their mathematical connection abilities. In order to achieve satisfactory learning outcomes. However, in fact, the mathematics learning process of students at school is still unable to apply the learning model that is in accordance with the material taught by the teacher to students.

Discovery Learning is a model used to solve problems intensively under teacher supervision. In Discovery Learning the teacher guides students to answer or solve a problem. Discovery learning is a cognitive learning method that requires teachers to be more creative in creating situations that can make students learn to actively find their own knowledge (Tanjung, D.F., et al. 2020; Assegaff, A and Sontani, U.T., 2016; Ana, N.Y., 2019; Damanik, W.J and 
IJEMS: Indonesian Journal of Education and Mathematical Science

2020 Vol. $x$, No. 1, pp.

$\operatorname{ISSN}(e): 2715-985 x$

DOI:

(C)2020IJEMS@UMSU.All Rights Reserved.

Syaputra, E. 2018; and Kurnianto, H., et al., 2015). The advantages of this Discovery Learning model, which are helping students to improve and improve cognitive skills and processes, arouse student interest in learning, generate pleasure in students, increase curiosity and foster self-confidence and can train students. Learn independently, train students' reasoning skills, and involve students actively in learning activities to find themselves and solve problems without the help of others (Prasetyo, S., et al., 2015; Assegaff, A and Sontani, UT., 2016).

The learning model Problem Based Learning is a learning model that is used to find solutions to problems in the real world. Model learning is developed to help teachers develop thinking skills and problem-solving skills in students as long as they learn the subject matter, can be done by providing a stimulus in the form of problems and then the students do the troubleshooting that can improve student mathematical metacognitive and connections. So that the problems given to students are so that there is curiosity about the learning problems given by the teacher (Royani, M., 2016; Mushlihuddin, R., et al. 2018; Tanjung, D. F., et al. 2020; Syafrizal, A., et al. 2020).

The advantages of the Problem Based Learning learning model, namely: (1) To train students to have the ability to think critically, to solve problems, and to build their own knowledge; (2) There is an increase in student scientific activity; (3) Encourage students to evaluate or assess their own learning progress; (4) Students are accustomed to learning through various sources of relevant knowledge; (5) Students are easier to understand a concept when discussing mutual problems encountered with his friend (Mushlihuddin, R., et al. 2018; Yanti, A. H., 2017; Rerung, N. 2017) .

Metacognitive abilities are very important in the learning process of mathematics. Learning with a metacognitive ability approach as learning that instills awareness of how to design, monitor, and control, about what students do or know (Sma, D. I. and Banyumas, N. 2015; Syahputra, E., 2018). In fact, students' metacognitive abilities lack student initiative in learning, poor student discipline in learning, less good student self-confidence in learning, and less good student responsibility in learning.

Mathematical connection ability is a person's ability to show internal and external mathematical relationships, which include: connections between mathematical topics, connections with other disciplines and connections with everyday life (Gunawan, Y. et al., 2019; Ni’mah, A. F. et al., 2017; Manalu, A. C. S., et al., 2020). Mathematical connections can make students have open thoughts and insights towards mathematics, not only focusing on one subject, but also connecting with other topics.

The low level of metacognitive abilities and student connections is caused by several things, including: lack of interaction between students and teachers, the lack of students 'ability to observe and recognize mathematical problems, students' low understanding of mathematical symbols, students are less active and tend to lack selfconfidence and those who the main thing is because learning is still teacher-centered. The purpose of this study was to determine the effect of the application of discovery learning and problem based learning models on students' metacognitive abilities and mathematical connections.

\section{METHODOLOGY}

This research is a quasi experimental research. The effect of the application of discovery learning and problembased learning models in this study is the pre-test post-test control group design. Research is conducted in UPT Formal Education Unit SMP Negeri 1 Percut Sei Tuan addressed in Jl. Besar Tembung, Percut Sei Tuan District, Deli Serdang Regency, North Sumatra Province.

Data collection techniques in this study were using tests and non-tests to measure students' initial mathematical abilities, metacognitive abilities, and mathematical connections, student activity observation sheets and the form of student answer processes. Data analysis techniques are divided into several analyses, including descriptive analysis and inferential analysis. The data description was carried out through descriptive analysis. The data described is data that has been obtained from measurements on the research variables (the dependent variable), namely the metacognitive abilities and mathematical connections of students at the pre-test and post-test. And for infrared analysis using assumption tests and hypothesis testing.

\section{RESULT AND DISCUSSION}

The results of the initial mathematics ability test for each class of the study sample can be seen in table 1.

Table 1: Description of the Initial Ability Test of the Two Experiment Classes

Descriptive Statistics
\begin{tabular}{|l|c|l|l|l|l|}
\hline & N & Min & Max & Mean & Std. Deviation \\
\hline KAMDL & 32 & 79 & 90 & 82.56 & 2,862 \\
\hline KAMPBL & 32 & 78 & 87 & 81.47 & 2,436 \\
\hline Valid N (listwise) & 32 & & & & \\
\hline
\end{tabular}

The table above shows that the students 'initial mathematical abilities seen from the 2 classes that will be used as the experimental class so that the maximum value of the students' initial mathematics abilities is 90.00 while the lowest score is 78.00. The average value for the experimental class 1 is 82.56, and the experimental class 2 is 81.47. The standard deviation of the experimental class 1 is 2.862, and the experimental class 2 is 2.436 . Table 2 
IJEMS: Indonesian Journal of Education and Mathematical Science

2020 Vol. $x$, No. 1, pp.

$\operatorname{ISSN}(e): 2715-985 x$

DOI:

(C)2020IJEMS@UMSU.All Rights Reserved.

presents the grouping of students' initial mathematical abilities using 2 learning models, namely discovery learning and problem-based learning.

Table 2: Quantitative Classification of Initial Math Ability of 2 Classes

\begin{tabular}{|l|l|l|l|}
\hline No. & \multicolumn{1}{|c|}{ KAM } & \multicolumn{1}{c|}{ Criteria } & \multicolumn{1}{c|}{ The number of students } \\
\hline 1. & KAM $\geq 86$ & High & 9 \\
\hline 2. & $80 \geq$ KAM $\geq 85$ & Medium & 51 \\
\hline 3. & KAM $\leq 79$ & Low & 5 \\
\hline
\end{tabular}

The data show that students' initial mathematical ability with moderate criteria is more dominant than their initial mathematics ability with high criteria and initial mathematics ability with low criteria. The metacognitive ability test result data is in the form of $\mathrm{KD}$ achievement test data from the discovery learning model which will be described consisting of pre-test data and post- test data. The retest was a metacognitive ability test given to both groups before being given treatment. The first group consisted of one experimental class I using the discovery learning model and the second group consisting of one experimental class II using the problem based learning model. In summary, the results of the metacognitive ability test in the experimental class I with the discovery learning model can be seen in table 3 below.

Table 3 Data Description of the Metacognitive Ability of the Discovery Learning Model Descriptive Statistics

\begin{tabular}{|l|l|l|l|l|l|}
\hline & N & Min & Max & Mean & Std. Deviation \\
\hline Metacognitive pre-test DL & 32 & 57 & 71 & 62.36 & 3,135 \\
\hline Post-test metacognitive DL & 32 & 72 & 80 & 77.20 & 2,161 \\
\hline Valid N (listwise) & 32 & & & & \\
\hline
\end{tabular}

The table above shows that the metacognitive ability seen from the experimental class I with the discovery learning model of the metacognitive ability seen from the pre-test obtained a maximum value of 71 so that the posttest obtained the maximum value was 80 while the lowest pre-test metacognitive ability value was 57 . While the post test was 72 The pre-test average score is 62.36 while the post-test score is 77.25. And the standard deviation of pre-test is 3.135 and posts are 2.161 . The grouping of the metacognitive abilities of the two experimental classes with a total of 64 students can be seen from the $\mathrm{N}$ description value of $14 \%$, the minimum description $25 \%$, the maximum description $32 \%$, the mean description $28 \%$ and the standard deviation $1 \%$. The results of the metacognitive ability test in the experimental class II problem based learning can be seen in table 4 below.

\section{Table 4: Data Description of Metacognitive Ability Model Problem Based Learning} Descriptive Statistics

\begin{tabular}{|l|c|c|c|c|c|}
\hline & N & Min & Max & Mean & Std. Deviation \\
\hline The metacognitive pre-test of PBL & 32 & 54 & 65 & 60.15 & 2,333 \\
\hline Post-test metacognitive PBL & 32 & 71 & 80 & 76.76 & 2,216 \\
\hline Valid N (listwise) & 32 & & & & \\
\hline
\end{tabular}

From the table above, the metacognitive ability seen from the experimental class II with a problem-based learning model, the metacognitive ability seen from the pre-test obtained a maximum value of 65 so that in the posttest the maximum value was 80 while the lowest pre-test metacognitive ability value was 54 while the post-test was 71 . The pre-test average value is 60.15 while the post-test is 76.76 . And the standard deviation of pre-test 2,333 and post-test 2,216. In the grouping of metacognitive abilities using line diagrams and circle diagrams with problembased learning models. From the grouping of the metacognitive abilities of the two experimental classes with a total of 64 students, it can be seen from the $\mathrm{N} 12 \%$ description value, $27 \%$ minimum description, $31 \%$ maximum description, $25 \%$ mean description and $1 \%$ standard deviation. The results of the students' math connection test in the experimental class I can be seen in table 5 below.

Table 5 Description of Student Mathematical Connection Data Model Discovery Learning Descriptive Statistics

\begin{tabular}{|l|c|l|l|l|l|}
\hline & N & Min & Max & Mean & Std. Deviation \\
\hline Pre-test connection DL & 32 & 60 & 73 & 66.58 & 3,966 \\
\hline Post-test connection DL & 32 & 78 & 89 & 83.63 & 3,480 \\
\hline Valid N (listwise) & 32 & & & & \\
\hline
\end{tabular}

The table shows that the students' mathematical connections seen from the experimental class I from the students' mathematical connections seen from the pre-test obtained a maximum value of 73 so that in the post-test the maximum score obtained was 89 while the lowest pre-test students' mathematics connection value was 60 . While the post-test score was 78 . The average pre-test is 66.58 while post-test is 86.63 . And the standard deviation of pretest 3,966 and post-test 3,480.

The grouping of students' mathematical connections from the two experimental classes with a total of 64 students can be seen from the description value of $\mathrm{N} 14 \%$, the minimum description $25 \%$, the maximum description $31 \%$, the mean description $28 \%$ and the standard deviation of $2 \%$. The results of the student's mathematics connection test in the experimental class II can be seen in table 6 below.

Table 6 Description of Student Mathematical Connection Data Model Problem Based Learning Descriptive Statistics

\begin{tabular}{|l|l|l|l|l|l|}
\hline & $\mathrm{N}$ & \multicolumn{1}{|c|}{ Min } & \multicolumn{1}{|c|}{ Max } & Mean & Std. Deviation \\
\hline Pre-test of the PPL connection & 32 & 59 & 66 & 61.77 & 2,000 \\
\hline
\end{tabular}


IJEMS: Indonesian Journal of Education and Mathematical Science

2020 Vol. $x$, No. 1, pp.

$\operatorname{ISSN}(e): 2715-985 x$

DOI:

(C)2020IJEMS@UMSU.All Rights Reserved.

\begin{tabular}{|l|l|l|l|l|l|}
\hline Post-test PBL connection & 32 & 77 & 85 & 81.84 & 2,096 \\
\hline Valid N (listwise) & 32 & & & & \\
\hline
\end{tabular}

The grouping of students' mathematical connections from the two experimental classes with a total of 64 students can be seen from the description value of $\mathrm{N} 14 \%$, the minimum description $27 \%$, the maximum description $30 \%$, the mean description $28 \%$ and the standard deviation $1 \%$.

The hypotheses tested to determine the normality of the data on students' initial mathematics abilities were:

$\mathrm{H}_{\mathrm{o}}$ : The sample comes from a population that is normally distributed.

$\mathrm{H}_{\mathrm{a}}$ : The sample comes from a population that is not normally distributed.

The normality test used the Kolmogorov Smirnov test with the help of the SPSS version 23.00 program which can be seen in table 7 below.

Table 7: Deskripsi early mathematical ability of students

Tests of Normality

\begin{tabular}{|l|l|l|l|l|l|l|}
\hline \multirow{2}{*}{ Class } & \multicolumn{2}{|l|}{ Kolmogorov-Smirnov a } & \multicolumn{3}{c|}{ Shapiro-Wilk } \\
\cline { 2 - 7 } & Statistics & df & Sig. & Statistics & df & Sig. \\
\hline KAMDL &, 172 & 32 &, 152 &, 869 & 32 &, 036 \\
\hline KAMPBL &, 145 & 32 &, 061 &, 849 & 32 &, 028 \\
\hline
\end{tabular}

The test criteria used to measure the normality of the population in this study are if the test results are significant ( $p$ value $>0.05$ ) then the data is normally distributed. Vice versa, if the significance $<0.05$, the data are not normally distributed. The results of the analysis of the normality test can be seen in table 8 below.

Table 8: Normality Test of Metacognitive Ability Model Discovery Learning

Tests of Normality

\begin{tabular}{|l|l|l|l|l|l|l|}
\hline \multirow{2}{*}{} & \multicolumn{3}{|l|}{ Kolmogorov-Smirnov a } & \multicolumn{3}{|c|}{ Shapiro-Wilk } \\
\cline { 2 - 7 } & Statistics & df & Sig. & Statistics & df & Sig. \\
\hline Metacognitive pre-test DL &, 118 & 32 &, $200^{*}$ &, 929 & 32 &, 038 \\
\hline Post-test metacognitive DL &, 150 & 32 &, 065 &, 930 & 32 &, 040 \\
\hline
\end{tabular}
*. This is a lower bound of the true significance.
a. Lilliefors Significance Correction

Based on the table above, it can be seen that the results of the pre-test and post-test metacognitive ability of the initial test on the discovery learning model have a pre-test significance value of 0.200 , and the post-test 0.065 is greater than the specified alpha value of $5 \%$ (0.05). It can be concluded that the research variables form a normal distribution to the population.

Table 9: Normality Test of Metacognitive Ability Problem Based Learning Model Tests of Normality

\begin{tabular}{|l|l|l|l|l|l|l|l|}
\hline \multirow{2}{*}{ The metacognitive pre-test of PBL } & \multicolumn{3}{|c|}{ Kolmogorov-Smirnov a } & \multicolumn{4}{|c|}{ Shapiro-Wilk } \\
\cline { 2 - 7 } & Statistics & df & Sig. & Statistics & df & Sig. \\
\hline Post-test metacognitive PBL &, 130 & 32 &, 181 &, 946 & 32 &, 109 \\
\hline
\end{tabular}

a. Lilliefors Significance Correction

Based on table 9 above, it can be seen that the results of the pre-test and post-test of metacognitive ability in the initial test on the problem-based learning model have a pre-test significance value of 0.181 and a post-test 067 which is greater than the set alpha value of $5 \%(0.05)$. It can be concluded that the research variables form a normal distribution to the population. The results of the student's mathematical connection normality test with the Discovery Learning model can be seen in brief in Table 10 below:

Table 10: Normality Test of Students' Mathematical Connection Model Discovery Learning Tests of Normality

\begin{tabular}{|l|l|l|l|l|l|l|}
\hline \multirow{2}{*}{} & \multicolumn{3}{|c|}{ Kolmogorov-Smirnov a } & \multicolumn{3}{c|}{ Shapiro-Wilk } \\
\cline { 2 - 8 } & Statistics & df & Sig. & Statistics & df & Sig. \\
\hline pre-test connection DL &, 155 & 32 &, 050 &, 920 & 32 &, 021 \\
\hline Post-test connection DL &, 101 & 32 &, $200^{*}$ &, 944 & 32 &, 095 \\
\hline
\end{tabular}

The result of the pre-test and post-test of the students' mathematical connection in the initial test on the discovery learning model had a pre-test significance value of 0.050 and a post-test 0.200 greater than the specified alpha value of $5 \%$ (0.05). It can be concluded that the research variables form a normal distribution to the population. Normality test connection students' mathematical model of problem based learning criteria test used to measure the normality of the population in this study is that if the test result was significant ( $p$ value $>0.05)$, the normal distribution of data. Vice versa, if the significance $<0.05$, the data are not normally distributed. In summary, it can be seen in table 11 below:

Table 11: Normality Test of Students' Mathematical Connection with Problem Based Learning Model Tests of Normality

\begin{tabular}{l|l} 
Kolmogorov-Smirnov a & Shapiro-Wilk
\end{tabular}


IJEMS: Indonesian Journal of Education and Mathematical Science

2020 Vol. $x$, No. 1, pp.

$\operatorname{ISSN}(e): 2715-985 x$

DOI:

(C)2020IJEMS@UMSU.All Rights Reserved.

\begin{tabular}{|l|l|l|l|l|l|l|}
\hline & Statistics & df & Sig. & Statistics & df & Sig. \\
\hline Pre-test of the PPL connection &, 186 & 32 &, 006 &, 925 & 32 &, 029 \\
\hline Post-test PBL connection &, 158 & 32 &, 042 &, 937 & 32 &, 062 \\
\hline
\end{tabular}

Based on table 11, it can be seen that the results of the pre-test and post-test of the mathematics connection of the students in the initial test on the problem-based learning model have a pre-test significance value of 0.006 and a post-test of 0.042 which is greater than the set alpha value of $5 \%(0.05)$. It can be concluded that the research variables form a normal distribution to the population.

The homogeneity test shows the students' initial mathematical abilities using the DL and PBL models that the significance value of the initial mathematical ability of the three experimental classes is $0.539>0.05$, it can be concluded that $\mathrm{H}_{0}$ which states the variance in each group is the same can be accepted, or prior knowledge of mathematics the two experimental classes have the same variance. The test criteria are determined if the significance (probability) values are generated together $\geq 0.05$, the population covariance variance matrix is the same. The homogeneity test of covariance variance for the pre-test and post- test of the students' initial and final metacognitive abilities obtained a significance of $0.535>0.05$. It can be concluded that at the $5 \%$ significance level the variance of the variable covariance is the same (homogeneous). The results of the calculation to see the variancecovariance homogeneity test for the final student post-test obtained significant $0.566>0.05$. It can be concluded that the $5 \%$ significance level of the variable covariance variance is the same (homogeneous). The test criteria are determined if the number of significance (probability) generated together is $\geq 0.05$, the population covariance variance matrix is the same. The results of the calculations for the homogeneity test of covariance variance for the pretest and post- test of the students' initial and final metacognitive abilities obtained a significance of $0.084>$ 0.05 . This means that it can be concluded that at the $5 \%$ significance level the variance of the variable covariance is the same (homogeneous). The results of the calculation to see the variance-covariance homogeneity test for the final student post-test obtained significant $0.350>0.05$. It can be concluded that the $5 \%$ significance level of the variable covariance variance is the same (homogeneous). The test criteria are determined if the significance (probability) values are generated together $\geq 0.05$, the population covariance variance matrix is the same. The results of the calculations for the homogeneity test of covariance variance for the pre-test and post-test of the students 'mathematical connection between the students' initial and final tests obtained a significance of $0.935>0.05$. The $5 \%$ significance level of the variance of the variable covariance is the same (homogeneous). The results of the calculation to see the variance-covariance homogeneity test for the final student post-test obtained significant $0.566>0.05$. It can be concluded that the $5 \%$ significance level of the variance of the variable covariance is the same (homogeneous). The test criteria are determined if the significance (probability) values are generated together $\geq 0.05$, the population covariance variance matrix is the same. The results of the calculations for the homogeneity test of covariance variance for the pre-test and post-test of the students 'mathematical connection between the students' initial and final tests obtained a significance of $0.538>0.05$. The conclusion that $\mathrm{t}$ are aft significance of $5 \%$ variance covariance variable is the same (homogeneous). The results of the calculation to see the variance-covariance homogeneity test for the final student post-test obtained significant 0.194> 0.05. The 5\% significance level of the variance of the variable covariance is the same (homogeneous).

Hypothesis first, second, third, fourth. for fifth, and sixth using the t test then the fifth hypothesis to six using the multivariate test (MANOVA). The first hypothesis test, namely the metacognitive t one sample test of the Discovery Learning model. Based on the results of data analysis on learning using discovery learning models to increase metacognitive abilities, it was obtained $t_{\text {count }}=5.767>t_{\text {table }}=2.040$. Thus $H_{0}$ is rejected. This means that discovery learning models are effective in improving metacognitive abilities. The second hypothesis test, namely the $t$ one sample test of the Discovery Learning model connection. Based on the results of data analysis on learning using discovery learning models to increase the ability of the connection obtained $t_{\text {count }}=14.019>t_{\text {table }}=2.040$. Thus $\mathrm{H}_{0}$ is rejected. This means that discovery learning model is effective in improving students' mathematical connections. The third hypothesis test, namely the $t$ one-sample metacognitive test of the Problem Based Learning model. Data analysis on learning using a problem-based learning model to increase metacognitive abilities obtained $t_{\text {count }}=4.493>t_{\text {table }}=2.040$. Thus $\mathrm{H}_{0}$ is rejected. That is, learning using problem based learning is effective in increasing metacognitive abilities. The fourth hypothesis test, namely the $t$ one-sample metacognitive test of the Problem Based Learning model. Based on the results of data analysis on learning using the Problem Based Learning model to increase metacognitive abilities, it was obtained $t_{\text {count }}=18.468>t_{\text {table }}=2.040$. Thus $\mathrm{H}_{0}$ is rejected. This means that discovery learning model is effective in improving students' mathematical connections. The output for the multivariate test (MANOVA) can be seen in table 12 below.

Table 12: Multivariate Test Results for Metacognitive Ability

Multivariate Tests a

\begin{tabular}{|c|c|c|c|c|c|c|c|}
\hline Effect & Value & F & $\begin{array}{c}\text { Hypothesis } \\
\text { df }\end{array}$ & $\begin{array}{c}\text { Df } \\
\text { error }\end{array}$ & Sig. & $\begin{array}{c}\text { Noncent. } \\
\text { Parameter }\end{array}$ & $\begin{array}{c}\text { Observed } \\
\text { Power }\end{array}$ \\
\hline
\end{tabular}


IJEMS: Indonesian Journal of Education and Mathematical Science

2020 Vol. $x$, No. $1, p p$

$\operatorname{ISSN}(e): 2715-985 x$

DOI:

(C)2020IJEMS@UMSU.All Rights Reserved.

\begin{tabular}{|l|l|l|l|l|l|l|l|l|}
\hline \multirow{5}{*}{ Intercept } & Pillai's Trace &, 999 & $29559,740^{\mathrm{b}}$ & 1,000 & 23,000 &, 000 & 29559,740 & 1,000 \\
\cline { 2 - 9 } & Wilks' Lambda &, 001 & $29559,74 \mathrm{O}^{\mathrm{b}}$ & 1,000 & 23,000 &, 000 & 29559,740 & 1,000 \\
\cline { 2 - 9 } & Hotelling's Trace & 1285,206 & $29559,74 \mathrm{O}^{\mathrm{b}}$ & 1,000 & 23,000 &, 000 & 29559,740 & 1,000 \\
\cline { 2 - 9 } & Roy's Largest Root & 1285,206 & $29559,74 \mathrm{O}^{\mathrm{b}}$ & 1,000 & 23,000 &, 000 & 29559,740 & 1,000 \\
\hline \multirow{5}{*}{ KAMDL } & Pillai's Trace &, 304 & $1,255^{\mathrm{b}}$ & 8,000 & 23,000 &, 313 & 10,043 &, 441 \\
& Wilks' Lambda &, 696 & $1,255^{\mathrm{b}}$ & 8,000 & 23,000 &, 313 & 10,043 &, 441 \\
\cline { 2 - 9 } & Hotelling's Trace &, 437 & $1,255^{\mathrm{b}}$ & 8,000 & 23,000 &, 313 & 10,043 &, 441 \\
\cline { 2 - 9 } & Roy's Largest Root &, 437 & $1,255^{\mathrm{b}}$ & 8,000 & 23,000 &, 313 & 10,043 &, 441 \\
\hline
\end{tabular}

a. Design: Intercept + KAMDL

b. Exact statistics

c. Computed using alpha $=.05$

The results of the analysis show the effect of the learning model with the same significance, namely $0.313<0.05$ for metacognitive abilities, which means that $\mathrm{H}_{0}$ is rejected. This means that there is an effect of discovery learning and problem-based learning models on metacognitive abilities. And that tests each variable individually. For the output between subject effects, the results can be seen in table 13. Based on table 13, the significance value for metacognitive variables is $0.313>0.05$, so $\mathrm{H}_{0}$ is accepted. This means that there is no difference in the value of metacognitive abilities between the experimental class I and the experimental class II.

Table 13: Results of the interaction test of early mathematical abilities and DL and PBL models on metacognitive abilities

Tests of Between-Subjects Effects

\begin{tabular}{|c|c|c|c|c|c|c|c|c|}
\hline Source & Dependent Variable & $\begin{array}{c}\text { Type III Sum of } \\
\text { Squares }\end{array}$ & $\mathrm{df}$ & $\begin{array}{c}\text { Mean } \\
\text { Square } \\
\end{array}$ & $\mathrm{F}$ & Sig. & $\begin{array}{c}\text { Noncent. } \\
\text { Parameter }\end{array}$ & $\begin{array}{c}\text { Observed } \\
\text { Power b } \\
\end{array}$ \\
\hline \multirow{2}{*}{$\begin{array}{l}\text { Corrected } \\
\text { Model }\end{array}$} & model & $43,998^{\text {a }}$ & 8 & 5,500 & 1,255 & ,313 & 10,043 & 4441 \\
\hline & Metacognitive & $43,998^{\mathrm{a}}$ & 8 & 5,500 & 1,255 & ,313 & 10,043 & 441 \\
\hline \multirow[t]{2}{*}{ Intercept } & model & 129504,148 & 1 & 129504,148 & 29559,740 & 000 & 29559,740 & 1,000 \\
\hline & Metacognitive & 129504,148 & 1 & 129504,148 & 29559,740 & , OOO & 29559,740 & 1,000 \\
\hline \multirow[t]{2}{*}{ KAMDL } & model & 43,998 & 8 & 5,500 & 1,255 & ,313 & 10,043 & 4441 \\
\hline & Metacognitive & 43,998 & 8 & 5,500 & 1,255 & ,313 & 10,043 & , 4411 \\
\hline \multirow[t]{2}{*}{ Error } & model & 100,765 & 23 & 4,381 & & & & \\
\hline & Metacognitive & 100,765 & 23 & 4,381 & & & & \\
\hline \multirow[t]{2}{*}{ Total } & model & 190875,083 & 32 & & & & & \\
\hline & Metacognitive & 190875,083 & 32 & & & & & \\
\hline \multirow{2}{*}{$\begin{array}{l}\text { Corrected } \\
\text { Total }\end{array}$} & model & 144,763 & 31 & & & & & \\
\hline & Metacognitive & 144,763 & 31 & & & & & \\
\hline
\end{tabular}

a. R Squared =, 304 (Adjusted R Squared =, 062)

b. Computed using alpha $=.05$

And to test the effect of the application of the two learning models on increasing metacognitive abilities, the results can be seen in table 14 .

Table 14: Marginal Mean Table

\begin{tabular}{|l|l|l|l|l|l|}
\hline \multirow{2}{*}{$\begin{array}{c}\text { Dependent } \\
\text { Variable }\end{array}$} & & \multirow{2}{*}{ Mean } & \multirow{2}{*}{ Std. Error } & \multicolumn{2}{|c|}{$95 \%$ Confidence Interval } \\
\cline { 3 - 6 } & & & & Lower Bound & Upper Bound \\
\hline \multirow{5}{*}{ model } & 79 & 78,000 & 2,093 & 73,670 & 82,330 \\
\cline { 2 - 6 } & 80 & 78,133 &, 662 & 76,764 & 79,503 \\
\cline { 2 - 6 } & 81 & 77,000 & 1,208 & 74,500 & 79,500 \\
\cline { 2 - 6 } & 82 & 75,600 &, 936 & 73,664 & 77,536 \\
\cline { 2 - 6 } & 83 & 77,000 & 1,480 & 73,938 & 80,062 \\
\cline { 2 - 6 } & 84 & 77,542 & 1,047 & 75,377 & 79,707 \\
\cline { 2 - 6 } & 85 & 79,000 & 1,480 & 75,938 & 82,062 \\
\cline { 2 - 6 } & 86 & 77,000 & 1,208 & 74,500 & 79,500 \\
\hline Metacognitive & 79 & 78,000 & 2,093 & 73,670 & 82,330 \\
\cline { 2 - 6 } & 80 & 78,133 &, 662 & 76,764 & 79,503 \\
\cline { 2 - 6 } & 81 & 77,000 & 1,208 & 74,500 & 79,500 \\
\cline { 2 - 6 } & 82 & 75,600 &, 936 & 73,664 & 77,536 \\
\cline { 2 - 6 } & 83 & 77,000 & 1,480 & 73,938 & 80,062 \\
\cline { 2 - 6 } & 84 & 77,542 & 1,047 & 75,377 & 79,707 \\
\cline { 2 - 6 } & 85 & 79,000 & 1,480 & 75,938 & 82,062 \\
\cline { 2 - 5 } & 86 & 77,000 & 1,208 & 74,500 & 79,500 \\
\hline
\end{tabular}

Based on table 14 above, for metacognitive variables, the mean Discovery Learning $>$ mean problem based learning is $80,000>78,500$. So it can be concluded that the discovery learning model is more influential in improving metacognitive abilities than the problem based learning model. 
IJEMS: Indonesian Journal of Education and Mathematical Science

2020 Vol. $x$, No. 1, pp

$\operatorname{ISSN}(e): 2715-985 x$

DOI:

(C)2020IJEMS@UMSU.All Rights Reserved.

Test multivariate (MANOVA) there are two parts, is the output multivariate tests which suggested a significant difference between the classes and and output between subject effects that tested each variable individually. The multivariate test output can be seen in table 15 below:

Table 15: Results of Students' Multivariate Mathematical Connection Test

Multivariate Tests ${ }^{\mathrm{a}}$

\begin{tabular}{|c|c|c|c|c|c|c|c|c|}
\hline \multicolumn{2}{|r|}{ Effect } & Value & $\mathrm{F}$ & $\begin{array}{c}\text { Hypothesis } \\
\text { df }\end{array}$ & $\begin{array}{c}\text { Error } \\
\text { df }\end{array}$ & Sig. & $\begin{array}{l}\text { Noncent. } \\
\text { Parameter }\end{array}$ & $\begin{array}{c}\text { Observed } \\
\text { Power }^{d}\end{array}$ \\
\hline \multirow[t]{4}{*}{ Intercept } & Pillai's Trace & ,999 & $10205,722^{b}$ & 2,000 & 21,000 & ,OOO & 20411,443 & 1,000 \\
\hline & Wilks' Lambda & ,001 & $10205,722^{\mathrm{b}}$ & 2,000 & 21,000 & , OOO & 20411,443 & 1,000 \\
\hline & Hotelling's Trace & 971,973 & $10205,722^{\mathrm{b}}$ & 2,000 & 21,000 & , OOO & 20411,443 & 1,000 \\
\hline & Roy's Largest Root & 971,973 & $10205,722^{\mathrm{b}}$ & 2,000 & 21,000 & , OOO & 20411,443 & 1,000 \\
\hline \multirow[t]{4}{*}{ KAMPBL } & Pillai's Trace &, 538 & ,901 & 18,000 & 44,000 &, 581 & 16,209 &, 520 \\
\hline & Wilks' Lambda &, 510 &, $935^{\mathrm{b}}$ & 18,000 & 42,000 &, 545 & 16,826 & ,533 \\
\hline & Hotelling's Trace & ,867 & ,964 & 18,000 & 40,000 &, 516 & 17,344 &, 543 \\
\hline & Roy's Largest Root & ,739 & $1,807^{\mathrm{c}}$ & 9,000 & 22,000 &, 124 & 16,265 & ,638 \\
\hline
\end{tabular}

The result of the analysis shows the effect of the learning model with the same significance, namely 0.581 $<0.05$ for the mathematics connection of the students, so it can be concluded that there is a difference in the effect of the application of learning using discovery learning and problem based learning models between the experimental class I and the experimental class II. And that tests each variable individually. For the output between subject effects, the results can be seen in Table 16 below:

Table 16: Tests of Between-Subjects Effects

Tests of Between-Subjects Effects

\begin{tabular}{|c|c|c|c|c|c|c|c|c|}
\hline Source & $\begin{array}{c}\text { Dependent } \\
\text { Variable }\end{array}$ & $\begin{array}{l}\text { Type III } \\
\text { Sum of } \\
\text { Squares }\end{array}$ & df & $\begin{array}{l}\text { Mean } \\
\text { Square }\end{array}$ & $\mathrm{F}$ & Sig. & $\begin{array}{l}\text { Noncent. } \\
\text { Parameter }\end{array}$ & $\begin{array}{c}\text { Observed } \\
\text { Power }^{c}\end{array}$ \\
\hline \multirow{2}{*}{$\begin{array}{l}\text { Corrected } \\
\text { Model }\end{array}$} & model & $39,653^{\text {a }}$ & 9 & 4,406 &, 922 &, 525 & 8,299 &, 334 \\
\hline & Connection & $68,519^{b}$ & 9 & 7,613 &, 546 & ,825 & 4,910 &, 200 \\
\hline \multirow[t]{2}{*}{ Intercept } & model & 97733,558 & 1 & 97733,558 & 20456,027 & ,OOO & 20456,027 & 1,000 \\
\hline & Connection & 118531,884 & 1 & 118531,884 & 8494,674 &, 000 & 8494,674 & 1,000 \\
\hline \multirow[t]{2}{*}{ KAMPBL } & model & 39,653 & 9 & 4,406 & ,922 &, 525 & 8,299 & ,334 \\
\hline & connection & 68,519 & 9 & 7,613 &, 546 &, 825 & 4,910 &, 200 \\
\hline \multirow[t]{2}{*}{ Error } & model & 105,110 & 22 & 4,778 & & & & \\
\hline & Connection & 306,981 & 22 & 13,954 & & & & \\
\hline \multirow[t]{2}{*}{ Total } & model & 190875,083 & 32 & & & & & \\
\hline & Connection & 224156,000 & 32 & & & & & \\
\hline \multirow{2}{*}{$\begin{array}{l}\text { Corrected } \\
\text { Total }\end{array}$} & model & 144,763 & 31 & & & & & \\
\hline & Connection & 375,500 & 31 & & & & & \\
\hline
\end{tabular}

a. R Squared =, 274 (Adjusted R Squared = -, O23)

b. R Squared =, 182 (Adjusted R Squared = -, 152)

c. Computed using alpha $=.05$

Based on table 16 above, the significance of the student's mathematical connection variable is $0.003<0.005$ $\mathrm{H}_{\mathrm{o}}$ is rejected. This means that there is an effect of the application of the value of the connection between students' mathematics in the experimental class I and the experimental class II. And to test the effect of implementing the two learning models on students' mathematical connections, the results can be seen in table 17 below:

Table 17: Marginal Table of Students' Mathematical Connections

\begin{tabular}{|c|c|c|c|c|c|}
\hline \multirow{2}{*}{$\begin{array}{l}\text { Dependent } \\
\text { Variable }\end{array}$} & \multirow{2}{*}{ KAMPBL } & \multirow{2}{*}{ Mean } & \multirow{2}{*}{ Std. Error } & \multicolumn{2}{|c|}{$\begin{array}{c}95 \% \text { Confidence } \\
\text { Interval }\end{array}$} \\
\hline & & & & $\begin{array}{l}\text { Lower } \\
\text { Bound }\end{array}$ & $\begin{array}{l}\text { Upper } \\
\text { Bound }\end{array}$ \\
\hline \multirow[t]{10}{*}{ model } & 78 & 78,000 & 1,546 & 74,795 & 81,205 \\
\hline & 79 & 77,000 & 2,186 & 72,467 & 81,533 \\
\hline & 80 & 77,885 & , 606 & 76,627 & 79,142 \\
\hline & 81 & 77,000 & 1,093 & 74,733 & 79,267 \\
\hline & 82 & 76,600 & 978 & 74,573 & 78,627 \\
\hline & 83 & 74,000 & 2,186 & 69,467 & 78,533 \\
\hline & 84 & 76,000 & 2,186 & 71,467 & 80,533 \\
\hline & 85 & 78,000 & 2,186 & 73,467 & 82,533 \\
\hline & 86 & 74,500 & 1,546 & 71,295 & 77,705 \\
\hline & 87 & 78,500 & 1,546 & 75,295 & 81,705 \\
\hline \multirow[t]{2}{*}{ Connection } & 78 & 83,500 & 2,641 & 78,022 & 88,978 \\
\hline & 79 & 85,000 & 3,735 & 77,253 & 92,747 \\
\hline
\end{tabular}


IJEMS: Indonesian Journal of Education and Mathematical Science

2020 Vol. $x$, No. 1, pp.

$\operatorname{ISSN}(e): 2715-985 x$

DOI:

(C)2020IJEMS@UMSU.All Rights Reserved.

\begin{tabular}{|l|l|l|l|l|l|}
\hline 80 & 83,462 & 1,036 & 81,313 & 85,610 \\
\cline { 2 - 7 } & 81 & 81,750 & 1,868 & 77,877 & 85,623 \\
\cline { 2 - 7 } & 82 & 83,000 & 1,671 & 79,535 & 86,465 \\
\hline 83 & 85,000 & 3,735 & 77,253 & 92,747 \\
\hline 84 & 86,000 & 3,735 & 78,253 & 93,747 \\
\hline 85 & 89,000 & 3,735 & 81,253 & 96,747 \\
\hline 86 & 86,000 & 2,641 & 80,522 & 91,478 \\
\hline
\end{tabular}

Based on table 17 above, on the student's mathematics connection variable, the mean discovery learning mean problem based learning is $83,400>80,400$. It can be concluded that discovery learning model is more influential on improving students' mathematical connections compared to problem based learning model.

The results of data analysis obtained from the experimental class I and experiment II show: (1) the effect of the application of the discovery learning model has an effect on increasing metacognitive abilities, (2) the effect of the application of the discovery learning model has an effect on improving students' mathematical connections, (3) the effect of application learning model of problem-based learning effect on improving metacognitive skills (4) the effect of the application of the learning model of problem-based learning effect on improving the connection of mathematics students, (5) the effect of the application of the learning model of discovery learning more influence on improving metacognitive skills than learning model of problem-based learning, (6) the effect of the application of the discovery learning model has an effect on increasing the mathematical connections of students than the problem based learning model , (7) the effect of the application of the discovery learning model influence on student learning activities, (8) there is an increase in metacognitive abilities through the application of the discovery learning model, (9) an increase in metacognitive abilities through the effect of the application of the problem based learning model, (10) an increase in students' mathematical connections through the effect of the application of the Discovery learning model. Learning, (11) an increase in students' mathematical connection through the application of learning models pro b glue based learning.

From the results of the calculations of the two experimental classes, the initial mathematical ability of the experimental class I with high criteria, amounting to 5 students, medium category 26 students and low category 2 students. Experiment class II with high criteria 4 people, medium criteria 25 students and low criteria 3 students. Of the total number of initial mathematical abilities with high criteria 9 people with a percentage of $13.23 \%, 51$ students with a moderate criteria of initial mathematics ability with a percentage of $81.54 \%$ and 5 students with a low criteria initial ability with a percentage of $5.23 \%$. From the two experimental classes, it was found that students with early mathematical abilities with moderate criteria were more dominant than students with high and low initial abilities.

To see the metacognitive abilities in the discovery learning models that have been carried out, the obtained tcount $=5.767>$ ttable $=2.040$. Which means that Ho is rejected? In other words, there is a significant influence between discovery learning models on metacognitive abilities (Masitoh, U., et al. 2019). Metacognitive ability in the problem based learning model obtained 77.2075 with a standard deviation of 2.161. Which means Ho is rejected. In other words, there is a significant influence between the problem based learning models on metacognitive abilities (Priyanti, D. 2018). The average score for metacognitive abilities from the discovery learning model is 2.161 .

To see the student's mathematical connection to the discovery learning model that has been done, it is obtained $83.63 \geq 45$ with a standard deviation of 3.480 , which means that $\mathrm{H}_{0}$ is rejected. In other words, there is a significant influence between discovery learning models on students' mathematical connections (Persada, A. R. 2016). Students' mathematical connections in the problem based learning model obtained $81.84 \geq 45$ with a standard deviation of 2.096, which means that $\mathrm{H}_{0}$ is rejected. In other words, there is a significant influence between the problem based learning models on students' mathematical connections (Herawat, L. 2017). The mathematical connection of students in the experimental class I, namely the class with the discovery learning model, can be seen from the discovery learning model of the students' mathematical connection 83.6345 with a standard deviation of 3,480 which means that $\mathrm{H}_{0}$ is rejected. In other words, there is a significant influence between discovery learning models on students' mathematical connections.

In the experimental class II, it can be seen that with the problem-based learning model of the students' mathematical connections, it is obtained $81.84 \geq 45$ with a standard deviation of 2.096, which means that $\mathrm{H}_{0}$ is rejected. In other words, there is a significant influence between the problem based learning models on students' mathematical connections.

From the results of the analysis of calculations that have been carried out on the effect of the application of discovery learning and problem-based learning models with students' initial mathematical abilities on metacognitive abilities which have a significant number on the variable post-test value $0.000<0.05$. By ignoring the effect of the application of discovery learning and problem-based learning models at the $95 \%$ confidence level, it can be concluded that there is a linear relationship between post-test scores and metacognitive abilities and covariant analysis assumptions that require linearity between covariant and dependent variables have been fulfilled. 
IJEMS: Indonesian Journal of Education and Mathematical Science

2020 Vol. $x$, No. 1, pp.

$\operatorname{ISSN}(e): 2715-985 x$

DOI:

(C)2020IJEMS@UMSU.All Rights Reserved.

To see the effect of applying discovery learning and problem based learning models, to connect math student, ignoring the effect of the initial capabilities of mathematics teaching model shows that the number of significance $0.000<0.05$. So it can be concluded that at the $95 \%$ confidence level there is an effect of discovery learning and problem based learning models on students' mathematical connections. To see the effect of the application of discovery learning and problem-based learning models on metacognitive abilities, it can be seen in the Corrected Model. The number of significance is $0.000<0.05$. This means that at the $95 \%$ level, the students' mathematics post-test and the difference between discovery learning and problem-based learning models. From the research results obtained by ignoring the effect of the initial mathematical ability of the model, it can be seen that the significance value for the post-test value is $0.061>0.05$, which means that $\mathrm{H}_{0}$ is accepted. By ignoring the influence of the learning model on the $95 \%$ confidence level and based on the survey that has been studied there is a linear relationship between the post-test and the students' mathematical connections.

To see the influence of the learning model of discovery learning and problem based learning to students' mathematical connections. By ignoring the effect of the initial mathematical ability of the model, it can be seen that the significance number is $0.003<0.05$, which means that $\mathrm{H}_{0}$ is rejected. So it can be concluded that at the $95 \%$ confidence level there is a significant influence between the learning models on students' mathematical connections. To see the effect of early mathematics abilities and differences in discovery learning and problem-based learning models on students' mathematical connections simultaneously, it can be seen in the Corrected Model. The significance value is $0.012<0.05$, which means that $\mathrm{H}_{0}$ is rejected. This means that at the $95 \%$ level, post-test and differences in discovery learning and problem-based learning models simultaneously (simultaneously) affect students' mathematical connections. For students' mathematical connections in discovery learning and problem-based learning models based on aspects of metacognitive abilities and connections as well, good student mathematical connections using discovery learning models. So that from the two models that have been used, the discovery learning model has a good effect on students' metacognitive abilities and mathematical connections than the problem based learning model.

\section{CONCLUSION}

From the results of the research that has been carried out, the following conclusions are obtained:

a. Model learning discovery learning and problem based learning has a positive influence on metacognitive skills and connections math students.

b. The metacognitive abilities and mathematical connections of students who are taught using the discovery learning model are better than the Problem Based Learning model.

c. There is an interaction between students' initial mathematical abilities and discovery learning and problem-based learning models that take place on metacognitive abilities

d. Against the interaction between students 'initial mathematical abilities and discovery learning models and problem based learning that takes place on students' mathematical connections

\section{REFERENCES}

Ana N. Y., (2019). Penggunaan Model Pembelajaran Discovery Learning Dalam Peningkatan Hasil Belajaran Siswa Di Sekolah Dasar. Pedagog. J. Ilmu Pendidik., vol. 18, no. 2, p. 56.

Assegaff, A and Sontani, U. T. (2016). "Upaya Meningkatkan Kemampuan Berfikir Analitis Melalui Model Problem Based Learning (Pbl),” J. Pendidik. Manaj. Perkantoran, vol. 1, no. 1, pp. 38.

Damanik, W. J. and Syahputra, E. (2018). Pengembangan Perangkat Pembelajaran Untuk Menigkatkan Kemampuan Berpikir Kreatif Matematis Siswa Menggunakan Model Discovery Learning. Inspiratif J. Pendidik. Mat., vol. 4, no. 1, pp. 27-38.

Gunawan, Y., Makur, A. P. and Jehadus, E. (2019). Pengaruh Model Pembelajaran Generatif Terhadap Kemampuan Koneksi Matematis Siswa Kejuruan. IndoMath Indones. Math. Educ., vol. 2, no. 2, p. 59.

Herawat, L. (2017). Peningkatan kemampuan koneksi matematik peserta didik menggunakan model problem based learning (PBL) dengan berbantuan Software Geogebra. J. Penelit. Pendidik. dan Pengajaran Mat., vol. 3, no. 1, pp. 39-44.

Irvan, Mushlihuddin, R and Suhartini. (2020). Effectiveness Of Learning Media Using Contextual Based Macromedia Flash for Junior School Students Al Hikmah Medan. IOP Conf. Series: Journal of Physics: Conference Series 1429 (1), 012002

Kurnianto, H., Masykuri, M. and Yamtinah, S. (2015). Pengaruh Model Pembelajaran Discovery Learning Disertai Lembar Kegiatan Siswa (Lks) Terhadap Prestasi Belajar Siswa Pada Materi Hidrolisis Garam Kelas XI Sma Negeri 1 Karanganyar Tahun Pelajaran 2014/2015. Jurnal. Pendidik. Kim. Univ. Sebel. Maret, vol. 5, no. 1, pp. 32-40.

Manalu, A. C. S.; Septiahani, A.; Permaganti, Melisari, B. M.; Jumiati, Y. and Hidayat, W. (2020). Analisis Kemampuan Koneksi Matematis Siswa SMK Pada Materi Fungsi Kelas XI. J. Cendekia J. Pendidik. Mat., vol. 4, no. 1, pp. 254-260.

Masitoh, U.; Suganda, O. and Widiantie, R. (2019). Pengaruh Model Pembelajaran Discovery Learning Dengan Alat Peraga Sederhana Terhadap Kemampuan Metakognitif. Quagga J. Pendidik. dan Biol., vol. 11, no. 1, p. 28. 
IJEMS: Indonesian Journal of Education and Mathematical Science

2020 Vol. $x$, No. 1, pp.

$\operatorname{ISSN}(e): 2715-985 x$

DOI:

(C)2020IJEMS@UMSU.All Rights Reserved.

Mushlihuddin R, Nurafifah and Irvan. (2018). The effectiveness of problem-based learning on students' problem solving ability in vector analysis course. IOP Conf. Series: Journal of Physics: Conf. Series 948(2018) 012028.

Mushlihuddin R, Wahyun, Sri and Irvan. (2018). The Influence of the PBL Model to Improve the Student's Mathematical Ability of Reasoning and Proof. Proceeding of The First AD Intercomme 2018. Jilid 1, pp. 46-51.

Ni’mah,A. F., Setiawani, S. and Oktavianingtyas, E. (2017). Analisis Kemampuan Koneksi Matematika Siswa Kelas IX A MTs Negeri 1 Jember Subpokok Bahasan Kubus dan Balok. J. Edukasi, vol. 4, no. 1, p. 30.

Persada, A. R. (2016). Pengaruh Model Pembelajaran Penemuan (Discovery Learning) terhadap Kemampuan Koneksi Matematika Siswa (Studi Eksperimen Terhadap Siswa Kelas VII SMPN 2 Sindangagung Kabupaten Kuningan Pada Pokok Bahasan Segiempat)," Eduma Math. Educ. Learn. Teach., vol. 5, no. 2, p. 23.

Prasetyo S., Usodo, B., and Subanti, S. (2015). Eksperimentasi Model Pembelajaran Discovery Learning (Dl) Dan Problem Based Learning (Pbl) Pada Materi Bangun Ruang Ditinjau Dari Kemandirian Belajar Siswa Kelas Viii Smp Negeri Se-Kabupaten Banyumas Tahun Pelajaran 2014/2015. Jurnal. Elektron. Pembelajaran Mat., vol. 33, no. 99, pp. 2339-1685.

Priyanti, D. (2018). Pengaruh Problem Based Learning (PBL) Terhadap Keterampilan Metakognisi dan Hasil Belajar Peserta Didik Pada Materi Pencemaran Lingkungan. Skripsi, 2018.

Royani, M. (2016). Problem Based Learning : Solusi Pembelajaran Matematika Yang Pasif. Math Didact. J. Pendidik. Mat., vol. 2, no. 2, pp. 127-131.

Rerung, N., Sinon, I. L. and Widyaningsih, S. W. (2017). Penerapan Model Pembelajaran Problem Based Learning (PBL) untuk Meningkatkan Hasil Belajar Peserta Didik SMA pada Materi Usaha dan Energi. J. Ilm. Pendidik. Fis. Al-Biruni, vol. 6, no. 1, p. 47.

Syafrizal, A., Edy Syahputra and Irvan. (2020). Differences in Increasing The Ability of Reasoning in Problem Based Learning Model and Computer-Based Group Investigation. Malikussaleh Journal of Mathematics Learning (MJML), Vol. 3, No. 2, pp. 51-56.

Syahputra, E. (2018). Differences in Metacognition and Mathematical Communication Ability Between Students Taught Using Problem Based Learning Model and Numbered Head Together Cooperative Learning Model at SMP Kartika I-2 Medan. J. Educ. Pract., vol. 9, no. October, pp. 30-37.

Sma, D. I. and Banyumas, N. (2015). Proses Metakognisi Dalam Pemecahan Masalah Matematika Pada Siswa Kelas XI Di Sma Negeri Banyumas. J. Elektron. Pembelajaran Mat., vol. 3, no. 9, pp. 1021-1034.

Tanjung, D. F., Syaputra E, dan Irvan. (2020). Problem Based Learning, Discovery Learning, and Open Ended Models: An experiment On Mathematical Problem Solving Ability. JTAM (Jurnal Teori dan Aplikasi Matematika). Vol. 4, No. 1, April 2020, pp. 9-16.

Yanti, Asria Hirda. (2017). Penerapan Model Problem Based Learning (PBL) terhadap Kemampuan Komunikasi dan Kemampuan Pemecahan Masalah Matematika Siswa Sekolah Menengah Pertama Lubuklinggau. J. Pendidik. Mat. Raflesia, vol. 2, no. 2, pp. 118-129. 